University of Nebraska - Lincoln

DigitalCommons@University of Nebraska - Lincoln

Publications from USDA-ARS / UNL Faculty

U.S. Department of Agriculture: Agricultural

Research Service, Lincoln, Nebraska

2009

\title{
Efficacy and safety of catnip (Nepeta cataria) as a novel filth fly repellent
}

\author{
J. J. Zhu \\ University of Nebraska-Lincoln, jerry.zhu@ars.usda.gov \\ X.-P. Zeng \\ Beijing Centre for Disease Prevention and Control \\ D. Berkebile \\ University of Nebraska-Lincoln, DENNIS.BERKEBILE@ars.usda.gov \\ H.-J. Du \\ Beijing Centre for Disease Prevention and Control \\ Y. Tong \\ Beijing Centre for Disease Prevention and Control \\ See next page for additional authors
}

Follow this and additional works at: https://digitalcommons.unl.edu/usdaarsfacpub

Part of the Agricultural Science Commons

Zhu, J. J.; Zeng, X.-P.; Berkebile, D.; Du, H.-J.; Tong, Y.; and Qian, K., "Efficacy and safety of catnip (Nepeta cataria) as a novel filth fly repellent" (2009). Publications from USDA-ARS / UNL Faculty. 396.

https://digitalcommons.unl.edu/usdaarsfacpub/396

This Article is brought to you for free and open access by the U.S. Department of Agriculture: Agricultural Research Service, Lincoln, Nebraska at DigitalCommons@University of Nebraska - Lincoln. It has been accepted for inclusion in Publications from USDA-ARS / UNL Faculty by an authorized administrator of DigitalCommons@University of Nebraska - Lincoln. 


\section{Authors}

J. J. Zhu, X.-P. Zeng, D. Berkebile, H.-J. Du, Y. Tong, and K. Qian 


\title{
Efficacy and safety of catnip (Nepeta cataria) as a novel filth fly repellent ${ }^{\star}$
}

\author{
J. J. Z H U $\mathrm{U}^{1}$, X. -P. Z Z N G ${ }^{2}$, D. B E R K E B I L E ${ }^{1}$, H. -J. D U $\mathrm{U}^{3}, \mathrm{Y} . \mathrm{T} \mathrm{O} \mathrm{N} \mathrm{G}$ and \\ K. Q I A N ${ }^{2}$ \\ ${ }^{1}$ Agroecosystem Management Research Unit, U.S. Department of Agriculture, Agricultural Research Service, University of \\ Nebraska, Lincoln, Nebraska, U.S.A, ${ }^{2}$ Institute of Disinfection and Pest Control, Beijing Centre for Disease Prevention and \\ Control, Beijing, China and ${ }^{3}$ Institute of Toxicology, Beijing Centre for Disease Prevention and Control, Beijing, China
}

\begin{abstract}
Catnip (Nepeta cataria) is known for its pseudo-narcotic effects on cats. Recently, it has been reported as an effective mosquito repellent against several Aedes and Culex species, both topically and spatially. Our laboratory bioassays showed that catnip essential oil (at a dosage of $20 \mathrm{mg}$ ) resulted in average repellency rates of 96\% against stable flies, Stomoxys calcitrans (L.) and 79\% against houseflies, Musca domestica (L.), respectively. This finding suggested that the application of repellent could be used as part of filth fly management. Further evaluations of catnip oil toxicity were conducted to provide a broad-spectrum safety profile of catnip oil use as a potential biting and nuisance insect repellent in urban settings. Acute oral, dermal, inhalation, primary dermal and eye irritation toxicity tests were performed. The acute oral $\mathrm{LD}_{50}$ of catnip oil was found to be $3160 \mathrm{mg} / \mathrm{kg}$ body weight (BW) and $2710 \mathrm{mg} / \mathrm{kg} \mathrm{BW}$ in female and male rats, respectively. The acute dermal $\mathrm{LD}_{50}$ was $>5000 \mathrm{mg} / \mathrm{kg} \mathrm{BW}$. The acute inhalation $\mathrm{LD}_{50}$ was observed to be $>10000 \mathrm{mg} / \mathrm{m}^{3}$. Primary skin irritation tested on New Zealand white rabbits showed that catnip oil is a moderate irritant. Catnip oil was classified as practically non-irritating to the eye. In comparison with other U.S. Environmental Protection Agency-approved mosquito repellents (DEET, picaridin and $p$-menthane-3,8-diol), catnip oil can be considered as a relatively safe repellent, which may cause minor skin irritation.
\end{abstract}

Key words. Musca domestica, Nepeta cataria, Stomoxys calcitrans, biting fly indoor bioassay, catnip, housefly, repellency, stable fly, toxicity evaluation.

\section{Introduction}

Flies and mosquitoes constitute two major groups of nuisance species in rural and urban environments worldwide. Many fly species are also called filth flies because of their association with contaminated substances, including food wastes, animal manure and carrion. The two major urban and livestock pest fly species in the world are houseflies, Musca domestica (L.), and stable flies, Stomoxys calcitrans (L.) (also called 'dog flies' or 'beach flies'). These are of considerable importance to people, pets and the tourist industry. Flies are also capable of becoming contaminated with more than 100 different pathogens (such as Salmonella and Campylobacter) that cause enteric infections and lead to the development of diseases in both human and animals (Bonnefoy et al., 2008).

Use of insect repellents is one of the most efficient ways to prevent disease transmission by biting insects, particularly by mosquitoes (Curtis, 1992; Gupta \& Rutledge, 1994). In many circumstances, application of repellents to the skin can be an effective way to directly reduce vector-host contact, which minimizes the incidence of disease transmission as well as the discomfort of insect bites (Fradin, 2001).

Fly control in urban areas is usually achieved by trapping techniques (baited, sticky traps and ultraviolet light traps), together with insecticide application technologies. However, there have been limited studies on the control of flies using

Correspondence: Dr J. J. Zhu, USDA-ARS Agroecosystem Management Research Unit, 305 Entomology Hall, University of Nebraska, East Campus, Lincoln, Nebraska 68583, U.S.A. Tel: + 1-402-472-7525; Fax: + 1-402-437-5712; E-mail: Jerry.Zhu@ars.usda.gov

* This article reports the results of research only. Mention of a proprietary product does not constitute an endorsement or a recommendation for its use by the U.S. Department of Agriculture. 
repellents. Although some insecticide-impregnated ear tags have been observed to be repellent to biting flies (mainly horn flies), very few have so far been reported for stable flies. Commercially available insect repellents can be divided into two categories: synthetic chemicals and plant-derived compounds made from essential oils. The most widely used mosquito repellent is N,N-diethyl-m-toluamide (DEET). A DEET analogue, $\mathrm{N}, \mathrm{N}$-diethylphenylacetamide, has been reported to repel stable flies in cage studies (Parashar et al., 1993).

Many plant extracts have been identified as having repellent effects (Coats, 1994; Isman, 2006). Researchers are now turning to folk remedies for novel chemistries and new repellent activities. Several reports have demonstrated varying degrees of mosquito repellency among plant oils, including clover, peppermint, geranium, neem and turmeric, etc. (Sharma et al., 1993; Kant \& Bhatt, 1994; Mafong \& Kaplan, 1997; Isman, 2006; Krajick, 2006;). Catnip (Nepeta cataria) is a herbaceous mint native to Eurasia and North Africa, which is also found in most of North America. It has been reported recently that topical application of catnip essential oil can effectively prevent biting by several disease-transmitting mosquito species, and there is additional evidence of spatial repellency (Peterson, 2001; Bernier et al., 2005; Trongtokit et al., 2005; Zhu et al., 2006). Although the effectiveness of catnip oil has been demonstrated on mosquitoes, the toxicity of this natural product repellent is largely unknown. Toxicity evaluations of most plant-based repellents have focused only on registered commercially available repellent products (U.S. Environmental Protection Agency [EPA] Biopesticide Registration Documents 011550 and $7505 \mathrm{C})$.

The present paper reports the results of catnip repellency tests on two fly species (stable flies and houseflies), and the outcomes of catnip toxicity studies including acute oral, dermal and inhalation toxicity tests, as well as evaluation tests of primary skin, eye and dermal sensitization.

\section{Materials and methods}

\section{Repellent}

Catnip essential oil was purchased from Bramble Berry Inc. (Bellingham, WA, U.S.A.). The purity of the oil was determined by gas chromatography-mass spectrometry; it comprised the major ingredient compounds of $(Z, E)$-nepetalactone and $(E, Z)$-nepetalactone (90\%), and caryophyllene (10\%) (Schultz et al., 2004).

\section{Insects}

Stable flies and houseflies used for laboratory repellency tests were sourced from colonies maintained at the U.S. Department of Agriculture, Agricultural Research Service, Agroecosystem Management Research Unit (Lincoln, NE, U.S.A.). The flies were maintained at $23 \pm 2{ }^{\circ} \mathrm{C}$ with variable humidity (30-50\% relative humidity $[\mathrm{RH}]$ ) and a light : dark (LD) photoperiod of 12:12 h. Adult stable flies were fed with citrated bovine blood
(3.7 g sodium citrate/L) by soaking a feminine hygiene pad (Stayfree ${ }^{\circledR}$; McNeil-PPC Inc., Skillman, NJ, U.S.A.) in blood and placing it on top of the cage. Houseflies were fed with a dry sugar-dry milk mixture made from products obtained from local grocery stores. Water was supplied ad libitum.

\section{Repellency assays}

The laboratory bioassay for testing repellent efficacy on fly biting and feeding consisted of a six-well feeding reservoir system similar to the K\&D module (Klun \& Debboun, 2000). A cage was set up with either stable fly or housefly pupae supplied with $10 \%$ sugar water. The sugar water was removed $24-48 \mathrm{~h}$ before the repellency test began. On the day of the test, small squares of the feminine hygiene pad $(3.75 \times 4.75 \mathrm{~cm})$ were cut to fit into the wells of the module. When testing stable flies, the pads were soaked with $\sim 5 \mathrm{~mL}$ of citrated bovine blood (sourced from a local abattoir). The outer layers of the feminine hygiene pads, which comprised two layers of $100 \%$ cotton flannel and a layer of ultra-thin nylon, were cut and coated with catnip oil. Catnip oil measured at three dosages, $0.2 \mathrm{mg}, 2 \mathrm{mg}$ and $20 \mathrm{mg}$, respectively, was dissolved in $300 \mu \mathrm{L}$ of hexane (Burdick \& Jackson Laboratories, Inc., Muskegon, MI, U.S.A.), then topically applied onto the outer layer evenly $(4 \times 5 \mathrm{~cm})$. After air drying, it was placed on top of the blood-soaked pad. Approximately three to five flies (stable flies starved for $48 \mathrm{~h}$ and houseflies starved for $24 \mathrm{~h}$ ) were collected from the fly cages and transferred into each testing cell. For houseflies, a 10\% sugar solution was used instead of the bovine blood. The solution was dyed with neutral red (1 g/100 mL; Sigma-Aldrich, St. Louis, MO, U.S.A.) to aid in the determination of feeding status at the end of the trial. After $4 \mathrm{~h}$, both stable flies and houseflies (anaesthetized with $\mathrm{CO}_{2}$ ) were checked for feeding status by squashing their abdomen to determine the presence of blood (stable flies) or red dye (houseflies) after the trials. Repellent assays were conducted daily at room temperature for $\geq 4 \mathrm{~h}$. Flies in the repellent bioassay were exposed to randomized treatments (different dosages), which were repeated until at least five replicates had been completed. Percentiles of repellency ([number of flies fed on control-number of flies fed on catnip]/number of flies fed on control $\times 100$ ) were determined and transformed to arcsine square-root values for analyses of variance (ANOVA). Significant differences at $P=0.05$ (SAS Version 10; SAS Institute, Cary, NC, U.S.A.) were determined by analyses performed on the least-square means as a result of the unequal number of observations among the treatments.

\section{Animals}

Adult Kunming mice (closed strain, see details in Yue et al., 2003; 18-21 g), Wistar rats (209-332 g) and New Zealand house rabbits were obtained from Beijing Laboratory Animal Centre, Institute of Microbiology and Epidemiology, Beijing. The animals were individually housed in wire cages $(20 \times 20 \times$ $22 \mathrm{~cm}$ ) containing bedding material (low-dust wood shavings) 
and given feed (laboratory animal food provided by the animal seller) and water ad libitum except during the experiment. Animal rooms were maintained at a constant temperature $\left(20-23^{\circ} \mathrm{C}\right)$ and humidity $(46-56 \% \mathrm{RH})$ and at LD 12:12 h. All animal experiments were performed in compliance with the Good Laboratory Practice (GLP) requirements of the Organization for Economic Cooperation and Development (OECD) Guidelines for Testing of Chemicals, and followed the standard protocols for the treatment of laboratory animals of the Beijing Centre for Disease Control and Prevention in accordance with an ethical review.

\section{Acute oral toxicity}

In the acute oral toxicity study, a single dose of catnip oil, diluted in corn oil, was given by oral gavages to mice of either sex at $1000 \mathrm{mg} / \mathrm{kg}, 2150 \mathrm{mg} / \mathrm{kg}, 4640 \mathrm{mg} / \mathrm{kg}$ and $10000 \mathrm{mg} / \mathrm{kg}$ body weight (BW). The rats were fasted for $16 \mathrm{~h}$ prior to dosing and returned to feeding $3 \mathrm{~h}$ after dosing. The mice were observed daily for 14 days for signs of toxicity and deaths. No differences in weights were found among the tested animals before and after the experiments. The analysis of mortality involved the calculation of the median lethal concentration $\left(\mathrm{LD}_{50}\right)$ of catnip oil using the method described in Zhu et al. (2006).

\section{Acute dermal toxicity}

In this study, a single high-limit dose of catnip oil, $5000 \mathrm{mg} / \mathrm{kg} \mathrm{BW}$, was applied to the clipped backs $(5 \times 5 \mathrm{~cm})$ of 10 male and 10 female Wistar rats, respectively. Catnip oil was injected under an occlusive rubber sleeve which surrounded the clipped trunk of each rat. The sleeve was removed after $24 \mathrm{~h}$, and the area was gently cleansed of any residual testing substance with mild warm water. Rats were examined daily for toxic signs during the 14-day experimental period.

\section{Acute inhalation toxicity}

In the acute inhalation study, Kunming mice (10 per sex) were exposed by the whole-body exposure technique for mice for $2 \mathrm{~h}$ at a concentration of $10 \mathrm{~g} / \mathrm{m}^{3}$ in a $0.1-\mathrm{m}^{3}$ exposure chamber equipped with a fan-based ventilation system. During the first 3 min of exposure, a heating system was activated. Animals were removed from the exposure chamber and provided with normal living conditions for 2 weeks to observe for signs of toxicity caused by the exposure.

\section{Primary skin irritation}

A primary skin irritation test was conducted on rabbits to determine the potential for catnip oil to produce an irritation after a single topical application. Four healthy female New Zealand White (NZW) rabbits $(2.3-2.5 \mathrm{~kg})$ were treated dermally with $0.5 \mathrm{~mL}$ of undiluted catnip oil by direct application to shaved intact skin of the left dorsal and trunk area $(3 \times 3 \mathrm{~cm})$. The same area of shaved skin on the right side of the animal was used as the control (no application). On the day before application, the test areas were covered with a semi-occlusive dressing for $4 \mathrm{~h}$. After the exposure period, the patches were removed and residual test material was wiped from the exposed skin using gauze moistened with distilled water. On the day of dosing, prior to application, the animals were given a health check and their skin condition was examined for any abnormalities. No pre-existing skin irritation was observed.

Individual evaluation of test dose sites was scored according to the Draize Scoring System (Table 1) at approximately $1 \mathrm{~h}$ after the removal of catnip oil (Draize et al., 1944; Draize, 1965) during a 14-day experimental period. The degree of irritancy was classified according to the descriptive rating for the mean primary dermal irritation index illustrated by Shara $e t$ al. (2005). The animals were also observed for signs of gross toxicity and behavioural changes at least once daily during the test period.

\section{Primary eye irritation}

Three healthy female NZW rabbits $(2.3-2.4 \mathrm{~kg})$ were treated with $0.1 \mathrm{~mL}$ of catnip oil. The upper and lower lids were gently held together for about $1 \mathrm{~s}$ before releasing to minimize loss of the test catnip oil. The treated (left) eyes of the animals were rinsed with physiological saline approximately $30 \mathrm{~s}$ after instillation of the test material. The non-treated right eyes were used as controls. The animals were observed at $1 \mathrm{~h}$, $24 \mathrm{~h}, 48 \mathrm{~h}, 96 \mathrm{~h}$ and $128 \mathrm{~h}$ post-instillation for any exhibited corneal opacity, iritis or conjunctival irritation (Table 2). For ocular observation, we used sodium fluorescein and ultraviolet light to detect corneal abnormalities (Kay \& Calandra, 1962). Rabbits assigned to the study had no observable pre-existing abnormalities.

Table 1. Scoring criteria for dermal reactions in the primary skin irritation study of catnip oil in New Zealand White rabbits.

\begin{tabular}{lc}
\hline I Erythema formation & Value \\
\hline $\begin{array}{l}\text { No erythema } \\
\text { Very slight erythema (barely perceptible with no defined }\end{array}$ & 0 \\
edges) & 1 \\
Slight erythema (pale red in colour with definable edges) & 2 \\
$\begin{array}{l}\text { Moderate to severe erythema (defined by colour with } \\
\text { well-defined area) }\end{array}$ & 3 \\
Severe erythema (coloured crimson red) & 4 \\
II Oedema formation & \\
\hline $\begin{array}{l}\text { No oedema } \\
\text { Very slight oedema (barely perceptible with no defined edges) }\end{array}$ & 1 \\
Slight oedema (edges of area well defined by definite raising) & 2 \\
$\begin{array}{l}\text { Moderate oedema (raised approximately 1 mm) } \\
\text { Severe oedema (raised }>1 \text { mm and extending beyond area of } \\
\text { exposure) }\end{array}$ & 3 \\
\hline
\end{tabular}


Table 2. Scoring criteria for ocular irritation in primary eye irritation study of catnip oil in New Zealand White rabbits.

\begin{tabular}{|c|c|c|}
\hline \multirow[t]{8}{*}{ I } & \multicolumn{2}{|l|}{ Cornea } \\
\hline & \multicolumn{2}{|l|}{ (A) Area of cornea involved } \\
\hline & No ulceration or opacity & 0 \\
\hline & $>0 \%, \leq 25 \%$ & 1 \\
\hline & $>25 \%, \leq 50 \%$ & 2 \\
\hline & $>50 \%, \leq 75 \%$ & 3 \\
\hline & $>75 \%, \leq 100 \%$ & 4 \\
\hline & Score $=A \times 3$ & Maximum total $=12$ \\
\hline \multirow[t]{6}{*}{ II } & Iris & \\
\hline & (A) Values & \\
\hline & Normal & 0 \\
\hline & $\begin{array}{l}\text { Markedly deepened rugae, congestion, swelling, circumcorneal injection (any or all of these } \\
\text { or combination thereof), iris still reacting to light (sluggish reaction is positive) }\end{array}$ & 1 \\
\hline & No reaction to light, haemorrhage, gross destruction (any or all of these) & 2 \\
\hline & Score $=A \times 3$ & Maximum total $=6$ \\
\hline \multirow[t]{7}{*}{ III } & Conjunctivae & \\
\hline & (A) Redness (refers to palpebral and bulbar conjunctivae excluding cornea and iris) & \\
\hline & Blood vessels normal & 0 \\
\hline & Some blood vessels definitely hyperaemic (injected above) normal & 1 \\
\hline & Diffuse, deeper crimson colour, individual vessels not easily discernible & 2 \\
\hline & Diffuse beefy red & 3 \\
\hline & Score $=A \times 3$ & Maximum total $=9$ \\
\hline \multicolumn{3}{|c|}{ Sum of all scores obtained } \\
\hline
\end{tabular}

\section{Results}

\section{Feeding repellency}

The repellency of catnip oil at three concentrations was tested on stable flies and houseflies using the modified K\&D module in the laboratory. Results are shown in Fig. 1. At $20 \mathrm{mg}$ and $2 \mathrm{mg}$, catnip oil demonstrated significant repellent activity against the feeding of both houseflies and stable flies, in comparison with that of control (in which feeding rates of 96-100\% were observed). The strongest repellency was observed at $20 \mathrm{mg}$ for stable flies. However, houseflies treated with $2 \mathrm{mg}$ catnip oil were repelled from feeding as effectively as those treated with $20 \mathrm{mg}$. When the dosage was decreased to $0.2 \mathrm{mg}$, no significant repellency was found for either species. No differences in repellency were found between the two fly species when tested under the same dosages (Student's $t$-test, $t=2.36-2.77, P>0.05)$.

\section{Acute oral toxicity}

Catnip oil, at doses of $1000-2150 \mathrm{mg} / \mathrm{kg} \mathrm{BW}$, did not cause mortality and did not induce any signs of toxicity in

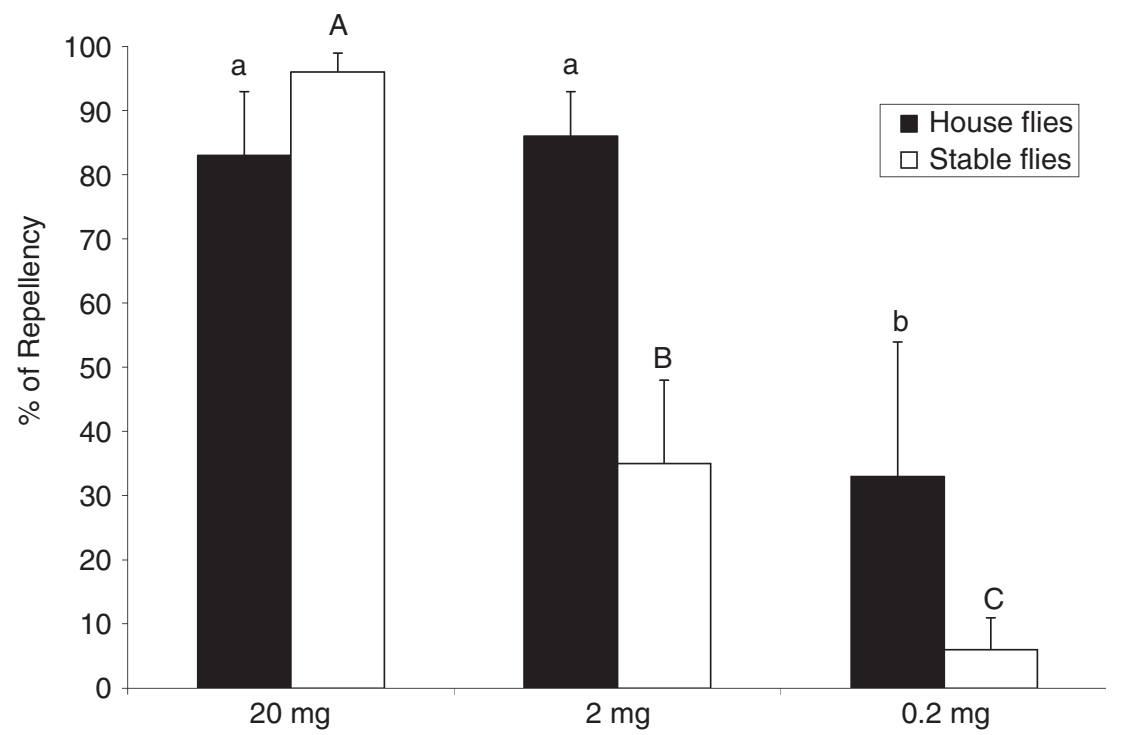

Fig. 1. Percentiles of feeding observed in starved flies treated with three different dosages of catnip oil in a modified K\&D module. Means with different letters are significantly different at $P<0.05$ (SAS Version 9.1, performed on the least-square means). 
the treated male and female mice following dosing (during the observation period of 14 days thereafter), except for the death of one male mouse. No gross pathological alterations were evident at terminal necropsy in any of the tested rats. Dose levels $>4640 \mathrm{mg} / \mathrm{kg}$ BW caused $100 \%$ mortality. The primary clinical signs of toxicity observed were decreased activity, wobbly gait and hyperhidrosis, respectively, in all female and male mice tested with dosages $>4640 \mathrm{mg} / \mathrm{kg}$ BW. One male mouse in the $2150-\mathrm{mg} / \mathrm{kg}$ group was found dead, but no abnormality was observed at necropsy. In the $4640-\mathrm{mg} / \mathrm{kg}$ BW group, most female mice died in the first 2 days and male mice died in the first day after dosing. In the group of mice treated at a dosage of $10000 \mathrm{mg} / \mathrm{kg} \mathrm{BW}$, both sexes died in the first day. However, necropsy revealed no abnormality. Based on these results, the median lethal dose $\left(\mathrm{LD}_{50}\right)$ of catnip oil was $3160 \mathrm{mg} / \mathrm{kg} \mathrm{BW}$ in female and $2710 \mathrm{mg} / \mathrm{kg} \mathrm{BW}$ in male mice.

\section{Acute dermal toxicity}

The acute dermal toxicity test was conducted using a single dose of topical application $(5000 \mathrm{mg} / \mathrm{kg} \mathrm{BW})$ on Wistar rats to determine the toxic potential of catnip oil. All animals survived and appeared active and healthy after the test. There were no signs of gross toxicity, dermal irritation, adverse pharmacological effects or abnormal behaviour. No gross abnormalities were noted for any of the animals at necropsy. Therefore, the acute dermal $\mathrm{LD}_{50}$ of catnip was found to be $>5000 \mathrm{mg} / \mathrm{kg} \mathrm{BW}$.

\section{Acute inhalation toxicity}

Neither death nor clinical signs of intoxication were observed to occur in groups of mice exposed to catnip oil at a concentration of $10 \mathrm{~g} / \mathrm{m}^{3}$. No gross abnormalities were noted in any of the treated mice after the 2 -week testing period. The $\mathrm{LC}_{50}$ of acute inhalation was $>10 \mathrm{~g} / \mathrm{m}^{3}$ for both sexes of mice.

\section{Primary skin irritation}

During the first 2 days following application of $0.5 \mathrm{~g}$ catnip oil, none of the four NZW rabbits were observed to show any signs of erythema or oedema. Slight erythema appeared on the treated area of one animal starting from day 3 and on the rest of the tested animals from day 4 . The erythema remained throughout the entire testing period (14 days) and no decrease in symptoms was observed. However, no oedema was noted in any tested animals during the period of the exposure test. The overall incidence and severity of irritation scores are presented in Table 3. No irritation on the skin of the control area was observed.

\section{Primary eye irritation}

None of the three rabbits exhibited signs of corneal opacity and iritis. Conjunctival irritation was revealed $1 \mathrm{~h}$ after test
Table 3. Primary dermal irritation scores in female New Zealand White rabbits after exposure to catnip oil.

\begin{tabular}{lccc}
\hline $\begin{array}{l}\text { Time } \\
\text { post-instillation, } \\
\text { days }\end{array}$ & Erythema & Oedema & Mean score* \\
\hline 1 & 0 & 0 & $0.00 \pm 0.00$ \\
2 & 0 & 0 & $0.00 \pm 0.00$ \\
3 & 1 & 0 & $0.25 \pm 0.25$ \\
4 & 4 & 0 & $1.00 \pm 0.00$ \\
$5-14$ & 4 & 0 & $1.00 \pm 0.00$ \\
\hline
\end{tabular}

*Mean values $(n=4)$.

Table 4. Incidence, severity and reversibility of ocular irritation in femaleNewZealand White rabbits after exposure to catnip oil $(n=3)$.

\begin{tabular}{lcccc}
\hline $\begin{array}{l}\text { Time } \\
\text { post-instillation, h }\end{array}$ & $\begin{array}{l}\text { Corneal } \\
\text { opacity }\end{array}$ & Iritis & Conjunctivitis & MMT value* \\
\hline 1 & $0 / 3$ & $0 / 3$ & $3 / 3$ & 1.0 \\
24 & $0 / 0$ & $0 / 0$ & $0 / 0$ & 0.0 \\
48 & $0 / 0$ & $0 / 0$ & $0 / 0$ & 0.0 \\
72 & $0 / 0$ & $0 / 0$ & $0 / 0$ & 0.0 \\
96 & $0 / 0$ & $0 / 0$ & $0 / 0$ & 0.0 \\
168 & $0 / 0$ & $0 / 0$ & $0 / 0$ & 0.0 \\
\hline
\end{tabular}

*MMT, maximum mean total.

material instillation, but did not persist for $24 \mathrm{~h}$. All control eyes remained free of any symptoms of eye irritation. The maximum mean total scores for catnip oil are listed in Table 4. No other signs of gross toxicity were observed during the testing period.

\section{Discussion}

The primary goal of the present study was to determine whether catnip essential oil can be used to effectively repel filth flies, including houseflies and stable flies, as it has been reported to do against mosquitoes. Furthermore, the study also aimed to evaluate the safety profile of catnip oil as a repellent before designating it as a safe alternative repellent against biting insects for practical application on humans and animals.

Stable flies and houseflies are the two major urban fly pests in the world. The management of these two fly species relies heavily on sanitation and pesticide application, which are difficult to implement because of high labour costs and the ineffectiveness of the available control products. Repellents have been used widely for personal protection against mosquito bites and the diseases they transmit. However, so far there have been very few studies conducted on the use of repellents against urban and agricultural fly pest species. The present study demonstrated that catnip essential oil has a significant repellent effect against these two urban fly pests. We observed repellency rates of $>96 \%$ against stable flies at a dosage of $20 \mathrm{mg}$ and of $86 \%$ against houseflies at a dosage 10 times lower, at $2 \mathrm{mg}$. This is the first study into the use of a plant-based essential oil to repel fly pests. Although the results from the K\&D module 
tests suggested a deterrent activity against feeding flies, the further tests conducted in our greenhouse cage study showed a spatial repellency, particularly against gravid stable flies in oviposition assays (unpublished data).

This study established a laboratory bioassay to screen substances that might serve as potential repellents against biting flies without the burden of using animals. The K\&D module was originally designed for the purpose of testing mosquito repellents in vitro. However, during the tests on flies in this study, no flies were observed to feed on either the blood or sugar water through the membranes (Baudruche membrane or Edical collagen) originally used for testing in mosquito research. Starved flies were observed to probe the membrane aggressively during the testing period, but were incapable of penetrating the layer of Baudruche or Edical collagen membranes employed in the $\mathrm{K} \& \mathrm{D}$ module for mosquitoes. This may reflect the result of differences between mosquitoes and muscid flies in mouth part structures. The mouth parts of stable flies were easily able to cut through the material used in the outer covering layer of the feminine hygiene pad for bloodfeeding. The control flies showed feeding rates of 96-100\%. The development of such an in vitro bioassay will contribute significantly to the future testing of other novel repellents for integrated fly management involving the pushand-pull strategy.

Although the use of botanically based repellents against mosquito bites has been widely accepted by the public, it is still very uncertain whether they are really safe for human and animal use. So far, only a very few plant-based repellents have been evaluated for toxicity. Most of them are EPAregistered commercial products. Catnip oil has been reported as an effective alternative insect repellent against several disease-transmitting urban insect pests, including mosquitoes and cockroaches (Peterson, 2001; Schultz et al., 2004; Bernier et al., 2005; Trongtokit et al., 2005; Zhu et al., 2006). In addition, catnip has been known historically as a folk remedy used to repel insects, and Eisner (1964) reported that it repelled at least 13 families of insects. The results from the present study demonstrated that catnip also effectively repels filth flies. Further toxicity tests showed no acute dermal toxicity or acute inhalation toxicity; therefore catnip falls into the category of 'virtually non-toxic'. The median lethal dose of catnip for acute oral toxicity in mice ranged from $2000 \mathrm{mg} / \mathrm{kg}$ to $3690 \mathrm{mg} / \mathrm{kg}$ BW (with a 95\% confidence interval), indicating very low toxicity. In the skin irritation study, no deaths or other signs of toxicity were observed, except that catnip caused slight erythema on tested rabbits. However, no oedema or other dermal findings were induced. This categorized catnip oil as being slightly irritating to the skin. The eye irritation test indicated that catnip could cause slight irritation, but evidence showed that all tested animals were free of ocular irritation within $24 \mathrm{~h}$.

The practice of using plant derivatives or botanically based insecticides and repellents in agriculture dates back at least two millennia to ancient China, Egypt, Greece and India (Schultz et al., 2004; Isman, 2006). Even in Europe and North America, the documented use of botanicals extends back more than 150 years, dramatically predating discoveries of the major

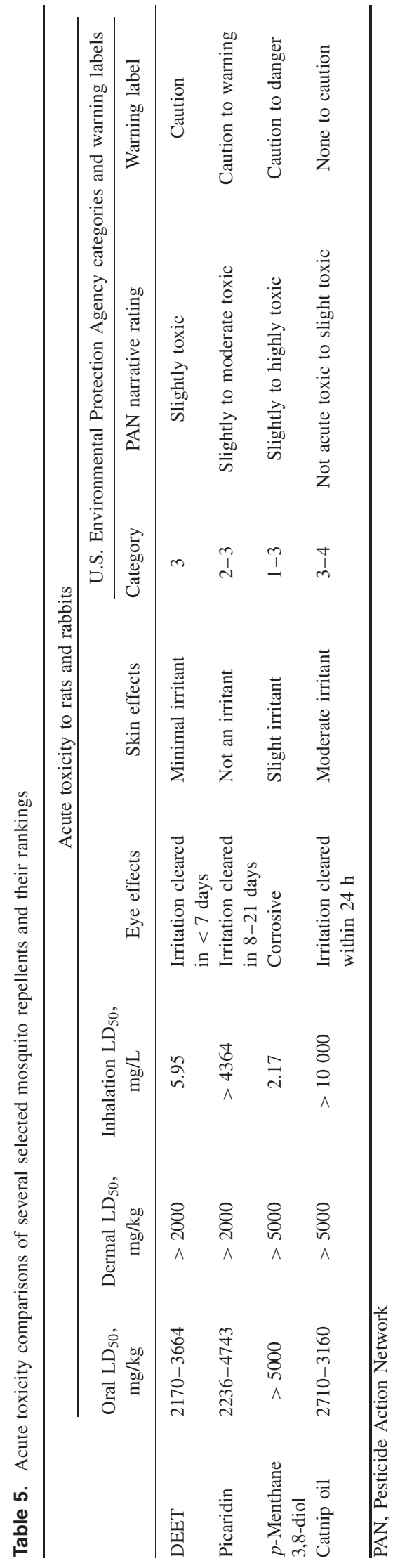

Journal compilation (C) 2009 The Royal Entomological Society, Medical and Veterinary Entomology, 23, 209-216 
classes of synthetic chemical insecticides. Recent studies have further proven their effectiveness as alternative mosquito repellents (Sukumar et al., 1991; Barnard, 1999; Thacker, 2002; Ware \& Whitacre, 2004; Trongtokit et al., 2005). So far, toxicity tests have been performed on only two plant-associated repellent compounds, para-menthane-3,8-diol (derived from the Australian lemon-scented gum tree) and picaridin (a synthetic derivative of pepper) (U.S. EPA Biopesticide Registration Documents 011550 and 7505C). Citronella oil, representing another group of botanically based insect repellents, was exempted from regulation under the Federal Insecticide, Fungicide and Rodenticide Act of 1996 because of its very low or non-toxicity, but it provided only very short-lived protection (Sukumar et al., 1991). Based on the EPA-published acute toxicity data for picaridin, para-menthane-3,8-diol and DEET (U.S. EPA DEET Registration Document), a comparative summary table (Table 5) was presented to show acute toxicity rankings based on the evaluation criteria of the U.S. EPA categories and warning labels adapted from the acute toxicity categories of the Pesticide Action Network Pesticide Database (http://www.epa.gov/oppsrrd1/REDs/0002red.pdf). In general, acute toxicity of catnip oil appeared to be extremely low because almost no gross signs of toxicity were noted. Catnip could be considered the least toxic of the four repellents compared. However, erythema occurred in all tested animals 4 days after topical application, which suggests that catnip oil may cause skin irritation. More extensive animal toxicology studies in conjunction with human clinical studies will need to be performed to establish the safety of catnip oil in humans and other animals before it can be fully accepted for use in personal and animal protection against biting insects.

\section{Acknowledgements}

We express our deep gratitude to T. Weinhold and L. Ma for their technical help with this study. This work was performed in co-operation with the Institute of Agriculture and Natural Resources, University of Nebraska-Lincoln, and supported partly by Regional Project 1030 .

\section{References}

Barnard, D.R. (1999) Repellency of essential oils to mosquitoes (Diptera: Culicidae). Journal of Medical Entomology, 36, 625-629.

Bernier, U.R., Furman, K.D., Kline, D.L., Allan, S.A. \& Barnard, D. (2005) Comparison of contact and spatial repellency of catnip oil and N,N-diethyl-3-methylbenzamide (DEET) against mosquitoes. Journal of Medical Entomology, 42, 306-311.

Bonnefoy, X., Kampen, H. \& Sweeney, K. (2008) Public Health Significance of Urban Pests, pp. 565. World Health Organization Regional Office for Europe, Copenhagen, 209-238.

Coats, J.R. (1994) Risks from natural versus synthetic insecticides. Annual Review of Entomology, 39, 489-515.

Curtis, C.F. (1992) Personal protection methods against vectors of disease. Review of Medical and Veterinary Entomology, 80, $543-553$.
Draize, J.H. (1965) The Appraisal of the Safety of Chemicals in Foods, Drugs and Cosmetics, Dermal Toxicity, pp. 46-59. Association of Food and Drug Officials of the U.S., Topeka, KA.

Draize, J.H., Woodward, G. \& Calvary, H.O. (1944) Methods for the study of irritation and toxicity of substances applied to skin and mucous membrane. Journal of Pharmacology and Experimental Therapeutics, 82, 377-390.

Eisner, T. (1964) Catnip: its raison d'être. Science, 146, 1318-1320.

Fradin, M.S. (2001) Protection from blood-feeding arthropods. Wilderness Medicine (ed. by P.S. Auerbach), 4th edn, pp. 754-768. Mosby, St. Louis, MO.

Gupta, P.K. \& Rutledge, L.C. (1994) Role of repellents in vector control and disease prevention. American Journal of Tropical Medicine and Hygiene, 50, 82-86.

Isman, M.B. (2006) Botanical insecticides, deterrents, and repellents in modern agriculture and an increasingly regulated world. Annual Review of Entomology, 51, 45-66.

Kant, R. \& Bhatt, R.M. (1994) Field evaluation of mosquito repellent action of neem oil. Indian Journal of Malariology, 31, 122-125.

Kay, J.H. \& Calandra, J.C. (1962) Interpretation of eye irritation tests. Journal of the Society of Cosmetic Chemists, 13, 281-289.

Klun, J.A. \& Debboun, M.A. (2000) New module for quantitative evaluation of repellent efficacy using human subjects. Journal of Medical Entomology, 37, 177-181.

Krajick, K. (2006) Keeping the bugs at bay. Science, 313, 36-38.

Mafong, E.A. \& Kaplan, H. (1997) Insect repellents: what really works? Postgraduate Medicine, 102, 63-69.

Parashar, B.D., Gupta, G.P., Sikder, N. \& Rao, K.M. (1993) Diethyphenylacetamide: a new insect repellent against stable fly, Stomoxys calcitrans. Medical and Veterinary Entomology, 7, 259-262.

Peterson, C.J. (2001) Insect repellents of natural origin: catnip and Osage orange, pp. 103-110. PhD dissertation, Iowa State University, Ames, IA.

Schultz, G., Simbro, E., Belden, J., Zhu, J. \& Coats, J. (2004) Catnip, Nepeta cataria (Lamiales: Lamiaceae). A closer look: seasonal occurrence of nepetalactone isomers and comparative repellency of three terpenoids to insects. Environmental Entomology, 33, $1562-1569$.

Shara, M., Yasmin, T., Kincaid, A.E. et al. (2005) Safety and toxicological evaluation of a novel niacin-bound chromium (III) complex. Journal of Inorganic Chemistry, 99, 2161-2183.

Sharma, V.P., Ansari, M.A. \& Razdan, R.K. (1993) Mosquito repellent action of neem (Azadirachta indica) oil. Journal of the American Mosquito Control Association, 9, 359-364.

Sukumar, K., Perich, M.J. \& Boobar, L.R. (1991) Botanical derivatives in mosquito control: a review. Journal of the American Mosquito Control Association, 7, 210-237.

Thacker, J.R.M. (2002) An Introduction to Arthropod Pest Control, pp. 28-49. Cambridge University Press, Cambridge, United Kingdom.

Trongtokit, Y., Rongsriyam, Y., Komalamisra, N. \& Apiwathnsorn, C. (2005) Comparative repellency of 38 essential oils against mosquito bites. Phytotherapy Research, 19, 303-309.

U.S. Environmental Protection Agency (2000) Regulating Pesticides. p-Menthane-3,8-diol Biopesticide Registration Eligibility Document. http://www.epa.gov/oppbppd1/biopesticides/ingredients/tech_docs/ tech_011550.htm. [Accessed 10 October 2008].

U.S. Environmental Protection Agency (2005) Pesticides and Toxic Substances (7505C) May 2005 New Pesticide Fact Sheet: Picaridin. http://www.epa.gov/opprd001/factsheets/picaridin.pdf. [Accessed 25 May 2005]. 
U.S. Environmental Protection Agency (1998) Regulating Pesticides. DEET. Biopesticide Registration Eligibility Document. http://www.epa.gov/oppsrrd1/REDs/0002red.pdf. [Accessed 1 September 1998].

Ware, G.W. \& Whitacre, D.M. (2004) The Pesticide Book, 6th edn, pp. 109-113. Meister Media Worldwide, Willoughby, OH.

Yue, B.-F., Liu, S.-H., Liu, D.-F., Hu, W.-P., Zhang, G.-M., Wang, L. \& Xing, R.-C. (2003) Comparative studies on the genetic biological markers of five closed colonies of Kunming mice. Laboratory Animal Science and Management, 20, 58-62.

Zhu, J., Zeng, X., Ma, Y. et al. (2006) Comparisons of adult repellency and larvicidal activity of plant essential oils against mosquitoes. Journal of the American Mosquito Control Association, 22, $515-522$.

Accepted 10 February 2009 